\title{
Arab-Byzantine Relations under the Umayyad Caliphate and South Caucasus
}

\author{
Nani Gelovani
}

\begin{abstract}
From the 7th century began struggle between the Arab Caliphate and the Byzantine Empire for the rule in South Caucasus (Soviet Transcaucasia). This struggle continued for a long time with changeable success. A comparison of the evidence of the various sources with historical facts already known and discussed earlier in historical literature enables in a number of cases to concretise or specify separate problems of the history of the Caliphate and of Byzantium in the early period of their interrelations. The 680s are one of the important periods in the history of Caliphate-Byzantine relations in South Caucasus. The paper discusses some questions of the title problem: the date of the Arab-Byzantine peace treaty, Arab-Byzantine Peace Agreements. These questions are discussed on the basis of a critical analysis of the evidence of various primary sources (Georgian, Armenian, Arabic, Syrian, Greek).
\end{abstract}

Index Terms-Arab caliphate, byzantine empire, south caucasus, caliphate-byzantine relations.

\section{INTRODUCTION}

The Arab-Byzantine Wars were a series of wars between the mostly Arab Muslims and the Byzantine Empire between the 7th and 11th centuries AD. These started during the initial Muslim conquests under the expansionist Rashidun and Umayyad caliphs in the 7th century and continued by their successors until the mid-11th century.

\section{ARAB-ByZANTINE PEACE TREATY}

\section{A. The Date of the Arab-Byzantine Peace Treaty}

The Byzantine historian Theophanes states that in the years 6178/686-687 between caliph 'Abd al-Malik (685-705) and emperor Justinian II (685-695, 705-711) was concluded the peace treaty, according to which the Byzantine Emperor agreed to withdraw Mardaites (Djarājima, in Arabic inhabitants of the Arabo-Byzantine border country. They played an important part during the early days of Islam in the wars between Arabs and Byzantines. To put an end to the attacks of these adventurers the caliph 'Abd al-Malik was compelled to sign a treaty with them, guaranteeing a weekly payment of 1,000 dinars) and in for this consideration caliph 'Abd al-Malik had to take upon himself obligation to pay to the Byzantines daily (The Arab chronicler al-Tabari reports much more credibly that a payment was to be made "every essembly day," i. e., Friday) one thousand gold pieces, one

Manuscript received September 3, 2012; revised November 12, 2012.

Nani Gelovani is with the Iv. Javakhishvili Tbilisi State University, Georgia (e-mail: nanagelov@yahoo.com). horse and one slave. But at the same time, the caliph had to surrender to the emperor half the tribute from Cyprus, Iberia (Kartli) and Armenia [1-5].

There does not seem to be any clear indication of how long this arrangement remained in force in Armenia and Iberia, but in Cyprus the condominium provision remained in effect for some two hundred and sixty years.

Before we examine the conditions of the peace treaty, it is necessary to precise, when it was concluded, as the data of the sources do not coincide with each other.

According to the evidence of Arab sources, the treaty was concluded in the year 69/688-89 or 70/689-90 [1], [6-7] and according to the Syrian sources in the year 997/685-86 [8-12].

We should note that Theophanes mentions this treaty in connexion with two particular years, 6176/684-85 and 6178/686-87. In 6176/684-85 'Abd al-Malik requested to renew the peace treaty with the same conditions as it was at the time of caliph Mu'awiya (661-680), and in 6178/686-87 the treaty was ratified. According to Theophanes, the latter coincides with the first year of Justinian's reign, i.e. 685 and the third year of caliph 'Abd al-Malik's reign, i.e. 687. The dates are contradictory, so it is necessary to check every information of Theophanes, concerning the year of conclusion of the peace treaty.

The fact that Byzantine historian Theophanes, Syrian and Arab authors dated the same year the rebellion of al-Ashdak ('Amr ibn Sa'id, known as al-Ashdak, Umayyad governor and general. In 69/689, when 'Abd al-Malik undertook a campaign against Irak, al-Ashdak took advantage of his absence to assert his right to the Caliphate and to stir up a dangerous revolt at Damascus. He was killed by 'Abd al-Malik himself in 70/689-90) [13], recall of the Mardaites from the territory of the Caliphate and the conclusion of the peace treaty, is to be taken into consideration. In consequence of the analysis of the sources we think that the Arab sources are more reliable.

As to Transcaucasia, the declaration of Theophanes that at the same time with the conclusion of the treaty, i.e. in 686-87 the emperor Justinian II sent the Byzantine general (strategos of the Anatolikon theme) Leontius to Armenia with the army is questionable. Leontius killed the Arabs, who were there and placed Iberia, Albania, Bukania (Mukan or Mughan is situated between the Armenia and Adharbadhagan) and Media (Media or Midiya is used in the text in a sense of Adharbadhagan/ at present Azerbaydjan) [14] under the Byzantines. He laid these countries under contribution and sent a great amount of money to the emperor [3]. In fact, he reports the treaty before he tells of Leontius's Armenian campaign (Arab sources show clearly that Theophanes' chronology cannot be accepted [2]. 
If we believe to the data of Theophanes, it is not clear, why did the Byzantine emperor sent his army to Armenia, for this was violation of the conditions, specified in the treaty. But Theophanes says nothing about this. He mentions later about the break of the treaty.

In the Arab sources, as far as we know, there is no information about this campaign. The data of Armenian sources are interesting.

According to the Armenian historian Ghevond, Justinian II sent his army to Armenia in second year of his reign. It sacked the country, turned it into ashes and returned to its homeland [15].

According to Asoghik of Taron, Justinian II in third year of his rule (687-688) sent his army to Armenia, it destoyed 25 districts and sold 8000 families as slaves [15-16]. According to same Asoghik, in the fourth year of Justinian's reign (689), the emperor himself leaded the campaign against Transcaucasia. He arrived to Armenia, divided his army into three and sent to Georgia, Albania and Armenia. Justinian summoned the rulers of these countries; took several of them with himself, took the children of others as hostages. Several of them he rewarded and nominated the governors of the mentioned countries: Nerse - the governor of Armenia and Varaz-Trdat - the exarch; left a troop of 30000 to help them and he himself returned to Constantinople [16].

There is an opinion, which we share that the above mentioned campaigns in Transcaucasia should be before conclusion of the peace treaty. Otherwise this would arouse corresponding reaction of the Caliphate [17-18]. Though several researchers note that the campaign against Armenia was violation of the peace treaty and that the caliph had not enough time for the counter-measures [19]. It is truth that caliph 'Abd al-Malik was beset by rivals for his throne (The caliph 'Abd al-Malik was not only engaged in a difficult war with anti-caliph Ibn al-Zubayr but also preoccupied with the revolt of the Umayyad 'Amr ibn al-Ashdak) and too busy to intervene effectively, but it is doubtful that he could leave without reaction the campaign of the Byzantines. We can show similar example in view of Cyprus. In 690-691 Justinian II decided to transplant the Orthodox population of Cyprus, what should be cause diminution of the income from the Island and, accordingly, the dissolution of the peace treaty. Despite of the situation in the Caliphate, 'Abd al-Malik did not agree with the decision of Justinian II and in 692 the peace treaty between Caliphate and Byzantium was broken.

Here is one more important note of Theophanes: 'Abd al-Malik, becoming aware of the campaign of the Byzantines in Caucasus, conquered Kerkisiya (orKarkisiya - a town in al-Djazira on the left bank of the Euphrates) and Theopolis (Theopolis or Antakiya - town in northen Syria, situated on the Orontes river). As is known, these towns were conquered more early, in 640. Though, we have to note, that in the Arab sources is mentioned the conquest of Kerkisiya at the time of 'Abd al-Malik too, - in 70/689-90 -71/690 -91 [20] i.e. this is in accordance with the words of Theophanes.

On the basis of everything, mentioned above, we consider the evidence of Arab sources more exact and think that the peace treaty was concluded in 688-689, and, so the Byzantine campaigns against Transcaucasia took place before conclusion of the peace treaty.

\section{B. Arab-Byzantine Peace Agreements}

As to the conditions of the peace treaty, according to Theophanes, Caliphate and Byzantium had to divide the tribute, collected from Armenia and Kartli equally. The Arab sources say nothing about division of the tribute.There also exists an eleventh-century Syrian chronicle, written by an individual known as Michael the Syrian who probably had access to sources unavailable to the Byzantine chroniclers. In his words, according the conditions of the Treaty, Armenia and the neighbour countries: Kartli (Djurzan), Arzan and the North part of Media, i.e. Atropaten Greek Atropaten, Armenian Atrapatakan, Adharbaydjan - one of the provinces of Media), stayed in the possession of Byzantines [8-9].

For establishing differences between Greek and Syrian sources, is important a note of Ghewond, preceding these events: during disturbances in Caliphate "after 30 years of obedience the Armenians, Georgians and Albanians ceased the payment of tribute. Their revolt continued for three years. On the forth year a people from the North, the Khazars conquered Armenia. Gregory, Prince of Armenia and many Georgian and Albanian nakharar-s and Princes were slain in battle. They themselves ravaged the country of Armenia, conquered many districts and settlements, took spoils and went to their country" [15],[21]. (Ghewond, 1862;10.

As notes Ghewond, this happened in the second year of 'Abd al-Malik's rule. Georgian scholar Acad. S. Djanashia notes that this fact should happen in the years 685-686, 30 years after the establishment of the Arab rule (655) in Kartli [14]. This date appears in Georgian historiography and thus, the above-mentioned Khazar invasion dates to 689 [22-23]. Although, we have to note that above noted issue was not the subject of special study of researchers.

The most of the researchers of the history of Armenia name the date of the revolt 680-682 years [24-26]. They mainly rely on the Khazar invasion (According to an anonymous seventh-century Armenian chronicle, this campaign is dated to 685; See also: [27-31]) the death of Gregory Mamikonian [15],[32] and, of course, 30 years from the establishment of Arab domination in Armenia [26].

In consequence of comparison of the sources it turns out that this uprising of the Transcaucasian peoples would take place in 681-682, in any case, before 685 .

We are not aware about the reaction from the part of the Caliphate. We can suppose that the revolt against Arabs would be successful, as the Arabs had not enough time to pay attention to Transcaucasia. But the Khazar invasion changed the situation considerably. In this battle they killed Gregory Mamikonian and the Princes of Georgia and Albania, but Levond does not mention them. In opinion of K. Toumanoff, in the struggle with Khazars perished Nerse, the erismtavar (prince) of Kartli [25].

In connection with Nerse, there is an interesting note of Ioavane Draskhanakerteli, an Armenian historian, according to which in the epoch of Armenian Catholicos Israel (Odmseli or Otmseli) some Baraba, - a leader in war of Arabian troops was driven out in Armenia by Nerse, Ishkhan of Virk (Kartli). The same information is given by Vardan[33]. Israel was a Catholicos of Armenia in 667-677 [34]. Though, according to several authors, Israel was Catholicos in 677-687; this date is 
to-day accepted In Georgian historiography and it is considered that in 686 the Erismtavar (prince) of Kartli was Nerse - the chief of the rebellion of the Transcaucasian peoples against Arabs, that, in our opinion, is to be precised. On the basis of analyse of the sources it seems to us that it is more correct that Israel was Catholicos in 667-677. The Erismtavar of Kartli Nerse is also mentioned in the preface of the Armenian translation of the Ecclesiastical History of Socrates.

Though, as notes S. Djanashia, the second part of the 7th century was such an epoch in Transcaucasia, when nobody could keep the achieved success for a long time. The Khazars also soon left for their country.

To understand the above-mentioned notes, we think that it would be rational to cast a glance at the situation of this period in Transcaucasia.

Before the expedition of Marwan ibn Muhammad (called Murvan Kru, "Marwan the Deaf," in Georgian sources) the relations between the Arabs and the Georgians were defined by the treaty, issued by Habib ibn Maslama. The Arabs obliged subdued side to pay the djizya, or poll-tax of one dinar per household. At the same time, according to the treaty, the Georgians and the Arabs are forbidden to join or divide families to avoid a reduction or increase of the djizya (For a detailed discussion of the subject, with indication of the relevant literature, see [35]). During the reign of caliph Mu'awiya Armenia annually paid 500 dahekans to the Caliphate [36].

As to Albania, according to a note of the Armenian historian Moses Kalankatuaci, in 62/681-682 Varaz-Trdat I on the meeting of Albanian rulers and Catholics declared: "The tribute we were laid under by the Arabian people is very heavy and oppresses and troubles us" [27]. So, it is quite natural that they could participate in the rebellion, narrated by Ghewond.

Byzantium immediately seized the opportunity of the situation in Transcaucasia. We suppose that the campaigns of Byzantines against Transcaucasia were a kind of respond to the above mentioned uprising, and as evenly notes M. Brosset, Justinian II wished to regain his authority in Oriental countries and sent Leontius to Armenia. After this 'Abd al-Malik concluded a peace treaty with Byzantium[37].

According to the note of Ghewond, examined by us, becomes clear that after the uprising in Transcaucasia the Armenians, Georgians and Albanians did not pay the tribute any more. Thus, the story told by Theophanes, who says that the Arabs and Byzantines should divide the tribute from Kartli and Armenia in equal parts, is doubtful. This kind of peace treaty shows that the rule of Arabs in these countries was restored.

Here arose one more question: If we believe to the data of the Armenian sources, until 686-693 Byzantium is the ruler of Armenia in fact [15-16]. Hence, Stratos doubts that the Byzantines divided the tribute with Muslims, as Theophane says [17].

In opinion of R-J. Lilie, it is doubtful that the Caliph could conclude this kind of treaty. 'Abd al-Malik was not able to fulfil the condition of a peace treaty, as the East provinces of the Caliphate were under the rule of Ibn al-Zubayr [38]. This, of course, is a very important argument. It also would be taken into account that in this period the main goal of 'Abd al-Malik was temporary regulation of the relations with Byzantium so that he could have the possibility of struggle inside the Caliphate.

In our opinion, the note of Michael the Syrian that Armenia, Kartli and Albania stayed under the rule of Byzantium temporarily is more correct. But let's follow the further advancement of events.

The peace treaty as it is known was concluded for period of ten years [8]. According to one of the Syriac Chronicle, treaty was concluded for periods of three years. According to Theophanes, in 6182 (690-691) the Byzantine Emperor broke the peace treaty. He conquered many Slavic tribes and relying on them he tried to break the Arabian army. The battle took place in 6183 (692-693) near Sebastopolis. Neboulos, the commander of a force of 30,000 men that had been recruited from the Slavs settled in Asia Minor, was bribed by the Arabs and together with 20,000 of his men came over to the Arab side, and the Byzantines consequently suffered a grave defeat. The situation in Transcaucasia was changed accordingly.

In 693 caliph 'Abd al-Malik nominated his brother Muhammad ibn Marwan the governor of Arminiya, al-Djazira and Azerbaidjan [6]. In the same year, as say the Byzantine sources, Sumbat Bagratuni, an Armenian patrician, after the defeat of the Byzantines led a revolt against Byzantine authority in that area, handed Armenia to the Arabians and surrendered to them himself. In 685 some Sergius (or Giorgi), son of Barnuk, patrician of Lazika (Egrisi) rebelled against the Byzantines and handed his country to the Arabs [32].

As to Albania, after the regulation of relations with Khazars Varaz Trdat I decided not to pay the tribute to the Byzantines. For that purpose in 699 he left for Constantinople for negotiations but Justinian II put him in prison because he got closer to the Caliphate and broke off any relations with Byzantium. In 704 Varaz Trdat I returned to his country and after that he paid tribute only to Arabs [39] 40( Dasxuranci, 1961;202-203).

\section{CONCLUSION}

Finally, an analysis of various sources permits the following conclusions:

1) The peace treaty between the caliph 'Abd al-Malik and the emperor Justinian II was concluded in 688-689.

2) In view of this, the mentioned campaigns of the Byzantines to Transcaucasia in 686,688 , and 689 must have taken place not after the conclusion of the peace treaty but before it, as Teophanes mentions.

3) The uprising of the Transcaucasian peoples, about which Ghewond informs us, took place in 681-682.

4) Under the terms of the treaty, Kartli, Armenia and supposedly Albania too, remaind under the dominations of the Byzantines.

\section{REFERENCES}

[1] Annales quos scripsit Abu Djafar Mohammed Ibn Djarir at-Tabari cum aliis edidit, M. J. de Goeje, ed. Leiden: E.J. Brill, 1879-1901, vol. I, pp. 797.

[2] E. W. Brooks, "The Arabs in Asia Minor (641-750), from Arabic sources," Journal of the Hellenic Studies, 18, pp. 182-208, 1898. 
[3] C. de Boor, Theophanis Chronographia recens, vol. 1, Leipzig: aedibus B. G. Teubneri, 1883, pp. 363.

[4] T. Kaukhchishvili, The Evidences of Greek Sources on the History of Georgia. Translated from the Greek. Tbilisi: Mecniereba, 1980, pp. 103.

[5] M. Canard, "Djarādjima," The Encyclopaedia of Islam (Web-CD edition. Brill Academic Publishers), vol. 2, pp. 456-458, 2003.

[6] I. Al-Athir, Al-K. Fi'L-Ta'Rikh, vol. 4, Beirouth: Dar Sader dar Beyrouth, 1965, pp. 306.

[7] Ph. K. Hitti, History of the Arabs, London: New York: St Martin's Press, 1961.

[8] Chronique de Michel le Syrien, Patriarche Jacobite d'Antioche (1166-1199), éditée pour le première fois et traduite en français par J. B Chabot, II, Paris: Ernest laroux, 1901, pp. 469.

[9] The Chronography of Gregory Abu'l Faraj Bar Hebraeus, Translated from the Syriac by E. A. W. Budge, vol. 1, London-Humphrey: Oxford University Press, 1932, pp. 103.

[10] E. W. Brooks. "A Syriac Chronicle of the year 846," Zeitschrift der Deutschen Morgenländischen Gesellschaft, vol. 51, pp. 560-61, 1897.

[11] Anonymi Auctoris Chronicon ad. annum Christi 1234 pertinens, trad. J. B. Chabot, repr. Louvain, Corpus Scriptorum Christianorum Orientalium, 109, Scriptores Syri, 56, 1952, pp. 227.

[12] Agapius (Mahboub) de Menbidj. Kitab al-unvan (Histoire Universelle). éditée et tradiute en français par A. A. Vasiliev, Patrologia Orientalis, VIII, fasc. 3, pp. 398-550, Paris: Librarie de Paris, 1912, pp. 497.

[13] M. Zetterstéen, "Amr b. Sa 'id al-Ashdak," The Encyclopaedia of Islam (Web-CD edition. Brill Academic Publishers), vol. 1, pp. 453-454, 2003.

[14] S. N. Djanashia, "Arab Rule in Georgia," in S. Djanashia(ed.) Works, vol. II, Tbilisi: Mecniereba, pp. 342-412, 1952.

[15] Istoriya khalifov Vardapeta Ghewonda [Ghewond's History], Translated from Armenian by K. Patkanov. St. Peterburg, 1862, pp. 16.

[16] Vseobshaiya Istoriya Stepannosa Taronskogo [World History of Stephanos de Taron], Translated from Armenian H. Emin. Moscow: Tipografia Lazarevskogo Instituta bostochnikh iazikov,1864,p.72 (in Russian).

[17] I. Stratos, Byzantium in the Seventh Century, vol. 5, Justinian II, Leontius and Tiberius III, 685-711. Amsterdam: Adolf M. Hakker, 1980, pp. 33.

[18] A. Müller, Istoriya Islama s osnovania do noveishikh vremion [A History of Islam from Its origin to Recent Time], 2, St. Petersburg: Izdanie L. F. Panteleeva, 1997, pp. 49.

[19] J. B. Bury, A History of the Later Roman Empire from Arcadius to Irene (395 A.D. to 800 A.D.), vol. II, London: London Macmillan, 1889 , pp. 321.

[20] I. Al-Athir, Al-Kamil Fi'L-Ta'rikh, vol. 4, Beirouth: Dar Sader dar Beyrouth, 1965, pp. 306.

[21] E. Tsagareishvili, "Armenian Sourses about the History of Arab-Georgian Relations," Mravaltavi, 5, pp. 464-496, 1971.

[22] N. Berdzenisvili, V. Dundua, M. Dumbadze, History of Georgia, vol. I, Tbilisi: Mecniereba, 1958.

[23] G. Abramishvili, Fresco Inscription of Stephanoz Mampali on the church of Ateni, Tbilisi: Mecniereba, 1977, pp. 25, 49.

[24] J. Laurent, L'Arménie entre Byzance et l'islam depuis la conquête arabe jusqu'en 886, Lisabonne, Laurent, 1980, pp. 227.

[25] C. Toumanoff, Studies in Christian Caucasian History, Washington DC: Georgetown University Press, 1963, pp. 398

[26] A. N. Ter-Ghevondian, "Le "Prince de'Arménie" a l'époque de la domination arabe," Revue des Etudes Armeniennes, 3, pp. 185-201, 1966.

[27] C. T. Eremyan, "Moisei Kalankatuiskii o posolstve albanskogo kniyaziya Varaz-Trdata k khazarskomu khakanu Alp-Ilitveru" [Movses Kalankatuaci about the mission of the Albanian ruler Varaz-Trdat to the Khazar's vassal "Alp-Ilituer"], Zapiski Instituta vostokovedeniya Akademii Nauk SSSR, vol. 7, pp. 129-155, 1939
[28] D. M. Dunlop, The History of the Jewish Khazars, Princeton, New Jersey: Princeton University Press, 1954, pp. 59-60.

[29] V. Minorsky, "A new Book on the Khazars," Oriens, Journal of the International Society for Oriental Research, 1(11), pp. 126, n. 2 1958.

[30] M. I. Artamonov, Istoriya Khazar [History of the Khazars], Leningrad:Gos.Ermitaj, 1962, pp. 190 (in Russian).

[31] A. A. Akopian, "O khronologii poslednikh sobitii v istorii 684 goda," Kavkaz i Bizantiya, 6, pp. 24-36, 1988

[32] J. Muyldermans, La domination arabe en Arménie. Extrait de l'Histoire universelle de Vardan. Traduit de l'arménien et annoté, Louvain-Paris, 1927, pp. 93, n. 3.

[33] Vseobshaiya Istoriya Vardana Velikogo [World History of the Vardan the Grate], Translated from Armenian H. Emin. Moscow, 1861, pp. 89

[34] I. Drasxanakertcia, Istoriya Armenii [History of Armenia]. Translated from Armenian M. O. Darbinian-Malikian. Erevan, 1986, pp. 153.

[35] O. Tskitishvili, "Habib b. Maslama's Kitāb al-amān in Abū 'Ubayd's treatise," Matsne, Series of History, Archaeology, Ethnography and Art History, 1, pp. 187-199, 1976 (in Georgian).

[36] E. Sikharulidze, "From the History of Arab-Georgian Relations (Arabic Kitāb al-amān)," Proceedings of Tbilisi State University, vol. 73, pp. 167-181, 1959

[37] M. Brosset, Additions et éclaircissements à l'histoire de la Géorgie depuis l'antiquite jusqu'en 1469. St-Pétersbourg: Impr. de l'acad. des sciences, 1851 , pp. 157

[38] R.-J. Lilie,Die Byzantinische Reaktion auf die Ausbreitung der Araber. Studien zur Strukturwandlung desByzantinischen Staates im 7. und 8. jhd., Munchen: Institut für Byzantinistik und Neugriechische Philologie der Universität, 1976, pp. 104

[39] Z. M. Bunyatov, Azerbaidjan v VII-IX vv. [Azerbaydjan in the 7th-9th centuries], Baku:Akademia Nauk Azerbaidjanskoi SSSR, 1966, pp. 106 (in Russian).

[40] The History of the Caucasian Albanians by Movses Dasxuranci, Translated by C. J. F. Dowsett, London: Oxford University Press, 1961, pp. 202-203.

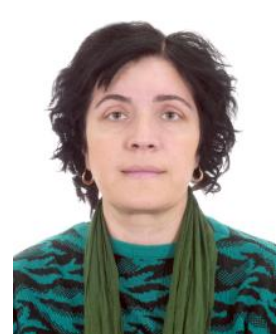

Nani Gelovani is an Orientalist. She graduated from the Faculty of Oriental Studies of the Tbilis State University(TSU) in 1983. She received her $\mathrm{PhD}$ (candidate of historical sciences) in World History from Tbilisi State University (Georgia) in 1991 and her $\mathrm{PhD}$ (doctor of historical sciences = habilitation) in World History from the Tbilis State University in 2005. Her research interests include; History of Islam; Islam and Gender Studies, History of Arab Countries.

Since 1984 she has been senior research fellow and then chief research fellow at the Acad. G.Tsereteli Institute of Oriental Studies, Georgia. In 1994-2005 she was Vice-Rector at the Georgian Open Humanitarian University. Since 1992 she is a Lectorer at the Iv Javakhishvili Tbilisi State University. Since 2006 until now she is associated professor at the Iv. Javakhishvili Tbilisi State University (Tbilisi, Georgia). Among the courses she teaches at the Faculty of Humanities of Tbilisi State University are the following: History of Islam, History of Islamic Law, Islam and Gender in the Modern Near East, Oriental Culture. She is the author of a number of books among which are Woman in Islam (7th-10th cent.) (Tbilisi, 2005, in Georgian), Islam (Religion, History, Civilization) (Tbilisi, 2009, in Georgian), and History of the Near East and Its Relationship with the South Caucasus (the 19th and the Beginning of the 20th Centuries) (Tbilisi, 2011, in Georgian, with co-authors).

Ms. Gelovani is currently the Deputy Chairman of the Institute of Oriental Studies, Iv. Javakhishvili Tbilisi State University, Georgia. 